\title{
French Research Institutes in the English-Speaking African Academic Market
}

\section{Marie-Emmanuelle Pommerolle}

\section{(2) OpenEdition}

1 Journals

\section{Electronic version}

URL: https://journals.openedition.org/eastafrica/1362

DOI: 10.4000/eastafrica.1362

ISSN: 2790-1076

\section{Publisher}

IFRA - Institut Français de Recherche en Afrique

\section{Electronic reference}

Marie-Emmanuelle Pommerolle, "French Research Institutes in the English-Speaking African Academic Market", Les Cahiers d'Afrique de l'Est / The East African Review [Online], 55 | 2020, Online since 16 November 2020, connection on 09 December 2021. URL: http://journals.openedition.org/ eastafrica/1362 ; DOI: https://doi.org/10.4000/eastafrica.1362

This text was automatically generated on 9 December 2021.

Les Cahiers d'Afrique de l'Est / The East African Review 


\title{
French Research Institutes in the English-Speaking African Academic Market
}

\author{
Marie-Emmanuelle Pommerolle
}

\section{AUTHOR'S NOTE}

This article was first published in French in Histoire de la recherche contemporaine (volume VIII, no. 2, 2019), in a special issue on "France-Africa Relations in the Academic Worlds » edited by Anne Doquet and Christophe Broqua: https://doi.org/10.4000/hrc. 3576.

\section{Introduction}

1 The relations between Africa and France most often implicitly designates relations between French-speaking Africa and France, including in the field of social science. From the 1970s, however, a few isolated French researchers created and established in English-speaking Africa modest research centres. They later integrated a research network that now includes twenty-seven French research institutes abroad, grouped into CNRS joint research units. ${ }^{1}$ French diplomacy initially supported these centres as it aimed to promote the production of French-speaking knowledge in countries hitherto little studied by French scholars: Kenya and East Africa; Zimbabwe, South Africa and its neighbouring countries; and last, Nigeria. The CNRS joined this network in 2007, making it possible to both strengthen the scientific credibility of what could be perceived as a primarily political enterprise, and internationalize French research.

2 This double supervision by the CNRS and French diplomacy may give the impression that these institutes have consolidated institutionally. Yet, their dominated position within each of these two supervising institutions and the extreme volatility of both 
diplomatic and scientific policies-which are constantly being "reformed"2-contribute to weakening these institutes. At the same time, and even if their trajectories of implantation in the academic fabrics of the countries where they are established are very heterogeneous, these institutes are all faced with university landscapes in full expansion and neoliberal transformation, notably through privatization, commodification and research programs funded through bids and calls. This contribution begins with shedding light on the structural fragility of these French research institutes abroad in order to explore, in a mirror image, the transformations of French "scientific diplomacy" and its policy of scientific internationalization, on the one hand, and those of the academic space of English-speaking Africa, on the other. The effects of these reforms, both in France and in Africa, depend on the historical trajectories of each national academic sector and are far from leading to the standardization of research spaces and practices (Provini 2015). Nevertheless, situated at the crossroads of these spaces under reform, the French institutes face multiple injunctions (e.g. project-funded research and commissioned research, increase in promotion and communication activities, and quest for "scientific excellence") while they continue to defend a specific "niche": qualitative and critical social science research. The main challenge for these research institutes is therefore not to reverse the structural inequality between French and African researchers, as is the case in partnerships with French-speaking Africa, but to make use of these common constraints and defend a type and conception of research which these many academic reforms are threatening, considering also the historical weight of the development sector on research. This reflection will be grounded mainly on the case of Kenya, where the author directed the French Institute for Research in Africa in Nairobi (IFRANairobi) between 2014 and 2018.

\section{Research Institutes in the Margins}

3 Created with the objective of filling the lack of French research in English-speaking African countries, French research institutes in sub-Saharan Africa are by nature marginal entities in the academic field they invested. They also have a marginal position within their two supervising institutions: research is by definition not the main activity of French diplomacy, and therefore of diplomats; and the international orientation of the CNRS represents only a tiny part of the activity of this state research institution. ${ }^{3}$ This doubly minority position, within both French and African institutional spaces, requires of these institutes that they comply with the rules of the game-rules which are rapidly changing and are not favourable to their specificity.

In East Africa, for instance, students, aspiring researchers and scholars have historically focused their attention to Great Britain, the former colonial power, and to the United States, a country that organized a system of scholarships for higher education at the time of the independence and that benefits from a global attractiveness, as well as to India or even South Africa (Charton 1997). The linguistic gap only adds to the minority position of the French university players in the Englishspeaking academic landscape. However, the place given to the French research institutes within the academic space of the countries where they are established depends on their own history. In Nigeria, the French Institute for Research in Africa (IFRA-Nigeria) in Ibadan is based in the country's oldest university, the University of 
Ibadan (UI). It has developed close relationships with UI professors and students, and it contributes to training them through a recurring fellowship program. Although IFRANigeria is the only foreign partner established there, the attractiveness of Englishspeaking academia challenges its position. For its part, the Research section of the French Institute of South Africa (IFAS-Recherche) in Johannesburg is part of a very dynamic university network which attracts many African students and researchers. Research prevails over training as South African universities largely provide for higher education. IFRA-Nairobi, for its part, has long-standing relationships with the oldest Kenyan universities, and on a more ad hoc basis with the universities of Uganda and Tanzania, but is located off campus, sharing its premises with its British counterpart, the British Institute of Eastern Africa, which is both IFRA's first collaborator and its first competitor when it comes to research implementation.

Despite their common minority position and competition from local or international partners, the French institutes in sub-Saharan Africa have steadily promoted research, publication and training of young researchers since the 1980s. After they became part of CNRS network in 2010, they gradually consolidated their recognized scientific knowledge (notably in urban studies, identity studies, and historical and archaeological issues ${ }^{4}$ ). They also developed their bilateral and transnational research networks thanks to various scientific programs funded through different sorts of research support mechanisms within the French Ministry of Foreign Affairs and the French National Research Agency (ANR). ${ }^{5}$ The training component of research, through various devices (e.g. scholarships and summer schools), strengthens these transnational networks through a common and early socialization of young researchers who then pursue their careers in a parallel and cross-over manner. The existence of a few Master's and PhD scholarships offered by the French government, allowing foreign students to spend a few months in French universities and support their Masters or $\mathrm{PhD}$ dissertation through co-supervision, also contributes to this pool of African researchers who socialize in French networks. However, the total number of these researchers is extremely small compared to those who study in English-speaking academia. The French policy of attracting foreign students was conceived as a means of increasing the number of African researchers exposed to French academia. In Kenya, the establishment of a Campus France office (within the Alliance française) with its dedicated staff seemed to be able to initiate this network extension. Regarding the increasing cost of studying in a Kenyan university since the implementation of a "cost sharing" policy (on which we come back to later), French cooperation services have widely used the argument of quality and almost free education in France to try to attract potential students relatively unfamiliar with the French context. But since the fall of 2018, the initiative labelled "Welcome to France," which has considerably increased registration fees for foreign students coming from outside of the European Economic Community (apart from $\mathrm{PhD}$ candidates), has weakened the already relatively marginal position of France in the English-speaking African academic space.

The dependence of the French research institutes-and of their attractiveness as wellon the hazards of diplomatic policy is a good reminder of the importance of the supervision of the French Ministry of Foreign Affairs (named "the Ministry" from now) over them. This non-academic supervision generates a certain number of fears within the research community. The possible politicization of the work of these French research institutes abroad seems largely fantasized or at least limited, but the structural dependence on a cooperation policy under perpetual reform is an element of 
fragility for them and for their conception of research, one that is not determined by development indicators. The potential political uses of the work of the research institutes are part of recurrent controversies between the Ministry (or rather, embassies) and researchers, as well as within the academic community. The problem, in fact, is not so much the political instrumentalization of researchers' work-their publications are accessible in any case-as the accumulation of orders given by the embassies for works that do not correspond to the priorities of researchers and of the institute or, possibly, the censorship exercised on certain subjects. As the balance of power is always present due to the hierarchical superiority of the ambassadors and cooperation chargés over the institute' directors, the latter most often look for the right distance from the diplomatic apparatus, responding to certain orders (particularly in terms of promotion and communication) while retaining control over the institute's research themes. The risks which the Ministry triggers are in fact not so much political as institutional. The evaluation reports of the research institutes written by their two supervising institutions, the Ministry and CNRS, are actually rather complimentary as they praise a unique international network that relies on low budget consumption. ${ }^{6}$ However, as the current reforms of the cooperation policy almost entirely fall into the hands of the French Development Agency (AFD), they are weakening the cooperation services and the research institutes that depend directly on them. ${ }^{7}$ Funded for the most part through the 185 program (i.e. "Cultural and influence diplomacy"), the research institutes are led by researchers recruited by the Ministry, to whom the CNRS sometimes temporarily assigns a researcher in addition to an annual allocation representing approximately $10 \%$ of the Ministry's grant (but these proportions vary). The issues raised by these financial and institutional allocations would not be so significant if they were not constantly the object of uncertainty and questioning, which reflects the dominated position of these research structures within the double supervision system they depend on. The CNRS, which uses the research institutes abroad network as a guarantee of its internationalization, finances this network only modestly and thus benefits from internationalization at relatively reduced costs. For its part, the Ministry, whose political orientations are much more decisive for the research institutes, has regularly hesitated about the usefulness, legitimacy and means to be entrusted to these institutes. Several episodes of mobilization of the scientific communities and their alliance with some Ministry agents interested in research made it possible to avoid certain reforms which would have been harmful to the autonomy of these structures. ${ }^{8}$

7 The gradual attribution of the cooperation powers to the AFD seems likely to call into question the institutional position of these institutes in a far more important way than hitherto. Now in charge of research, higher education, governance, etc., the AFD drains budgets that are out of comparison with those of cooperation-in very sharp declineand intervenes in the fields covered by the research institutes (research, higher education) but according to a very different logic. First, the AFD research service, mainly staffed by economists, acts as a recipient of European funds in particular, which they then seek to disburse, in partnership with African academics, yet without consulting the research institutes for the moment.9 Secondly, in the field of higher education, the AFD operates as a bank, and therefore seeks to lend to governments so they can build new university and research infrastructures. Again, the research institutes, which are only competent in the production of knowledge, are seldom consulted and rarely associated to combine infrastructure and research projects. This 
shift of scientific skills to the AFD is very recent and has no direct consequence, for the time being, on the institutes' operations, except for the consequent drop in subsidies. The few local collaborations between the AFD and French research institutes may pave the way for new relationships and a new positioning of these institutes in French scientific diplomacy policy, but uncertainty prevails because it radically transforms the historical rationale of scientific cooperation. The role and mission of the AFD are indeed both the cumulated outcome of the previous cooperation reform that suppressed the then "Ministry of Cooperation" yet retained its staff and its skills, and the advent of a policy of agency or "agencification" (AFD, French Institute, Campus France) that are part of and contribute to a more global tendency to neoliberal bureaucratization (Meimon 2007). Will the French research institutes integrate this logic (and eventually be absorbed by an agency?) or will they continue to navigate their double supervision and benefit from the (relative) weight of the academic community? The fact remains that these transformations affecting French development policy-but also France's academic space-echo those experienced by research and the university in the African English-speaking countries in which the French research institutes are established.

\section{University Reforms and Academic Excellence}

8 Turning to universities, which are in full development, seems a natural move for French researchers as they come themselves from universities. Universities are actually in majority the traditional partners of the French research institutes abroad. However, the multiplication of university reforms and the exponential growth of the university sector have had ambivalent effects on research production at university and on the development of joint research projects..$^{10}$ Since the end of the 1980s and structural adjustment policies, university reforms have transformed the 'governance' of universities: they now work in particular thanks to the so-called "self-sponsored" students, that is, those who pay their tuition at high prices. ${ }^{11}$ The underlying aim is therefore to always attract more, to multiply the university offer, both in disciplinary and geographic terms. In Kenya, campuses are expanding in the territory, to the point that President Kenyatta ordered the end of this expansionism which would take place at the expense of the "quality" of education. ${ }^{12}$ This trend of university growth, which also responds to the massification of higher education and a dynamic economic market, goes hand in hand with the integration of Kenya's academia into the international academic market. The circulation of standards promoted by the reforms includes the objective of "scientific excellence"; universities, especially the historical ones, make sure to place research at the center of their activities.

In this context, the career of academics is subject to a contradictory double order. On the one hand, they have to respond to the growing demands related to teaching. On the other hand, the career promotion of scholars is indexed to their research activity, and in particular to their publications. Applied quantitatively and sometimes following a purely formal rationale, such criteria can lead to the publication of articles in unreferenced online journals one often has to pay for, which are often mocked by the scholars themselves but which help them meet sometimes extravagant requirements: to register for a doctorate, it is now compulsory to have published two articles in academic journals. ${ }^{13}$ These requirements also give rise to the revival of the promotion 
of research activities by universities, to the support of in-house journals and to the reappropriation of scientific events hitherto organized outside the continent. The Africa Review, published by the political science department of the University of Dar es Salaam (UDSM) and in which IFRA in Nairobi was able to publish a special issue, is a good example of these internal and valued publications. It is considered to be UDSM's first and best publications. As far as scientific events are concerned, which are back on the continent, one can mention the African Studies Association of Africa. Its objective is to repatriate African Studies research on the continent. Until then, the main congresses of African Studies were taking place in the United States (annual conference of the African Studies Association [ASA]) and in Europe (European Conference of African Studies, ECAS). This appropriation of the references of academic excellence produces effects similar to those which the European and French academic spaces have seen. The major universities (the oldest ones in East Africa, like the University of Nairobi, UDSM and Makerere University, as well as private universities) succeed in getting the resources of "excellence" through the organization of events and research projects in cooperation. For their part, regional universities, in spite of their international relations services and network building, find it more difficult to meet these requirements and to attract the best-rated students and professors. This gap between internationalized universities and local universities can also be found in the French academic landscape (Musselin 2017). The dualization of the market makes it difficult for the French research institutes abroad-being situated in the margins-to cooperate with the best-endowed universities that look to other partners endowed with the capacity to offer greater research and career opportunities. The weight of the field of development on research and the attractiveness of projects funded by actors outside the university realm-which is an older and known phenomenon on the African continent-accentuate this pattern. Again, the French research institutes are not the best equipped to penetrate this market, as are many of their African counterparts.

\section{Two Intertwined Domains: Development and Research}

10 The question of the relative autonomy of research from all sorts of donors is not new in Africa. Indeed, funding for "development" often coincided with funding for research for development. Development and academia, which both comprise educated and relatively cosmopolitan individuals, overlap and often meet on the continent. The mission of some of the French research institutions working in "the South" is actually to coordinate research and development, fostering the circulation of their researchers -and of their researchers' colleagues-from one domain to the other (IRD, CIRAD, for instance). However, the relationship between these two domains is deeply asymmetrical: the financial capital of development has no comparison with that of research and university. The consequences of this unequal relationship are manifold. They often materialize in the provision of "per diem" paid to academics when they present research papers, and is visible in the enthusiasm of academics for consultancy. ${ }^{14}$ This unequal relationship can, in some cases, profoundly transform research structures, researchers' careers and the very topics of research. Like Addis Ababa and Dakar, Nairobi is an "international hub" that hosts one of the three United Nations headquarters, numerous NGOs and international foundations that all work in the 
region. As a consequence, development weigh in heavily on research. This is less the case in Ibadan or Johannesburg.

In East Africa, a large part of knowledge production-which actors gather together under the label of "research"-takes place outside academic institutions. Being the product of commissioned research or funded through bids and calls, the activities of knowledge production sometimes rely upon a ground-breaking scientific approach based on empirical data, yet they also often derive from second-hand data collection and are fostered by the perspective of project assessment. This is the case of the very common "baseline studies": they are supposed to initiate projects, either in research, or for development interventions.

The research market is manifestly a two-tier market: on the one hand, a large number of think tanks, private institutes and national consultancy firms are headed by Kenyan academics (in office or not) who produce reports, studies, and evaluations, or offer the service of these academics within projects led by others; on the other hand, international NGOs, foundations and think tanks, based in Nairobi, dominate the market as they are directly connected to Western funders and bring together African researchers as well as foreign researchers. A report commissioned by DFID ${ }^{15}$ and put together by Development Initiatives (an international NGO) offers the mapping and analysis of the production of knowledge in the humanitarian field (conflicts, health, etc.) in East Africa. Based on interviews with actors involved in this type of research activity, this report confirms both the segmentation and hierarchy of the institutional landscape and the implicit desire of international actors, donors and NGOs, to maintain this dynamic (Development Initiatives 2016). The report mainly observes that research is dominated by international actors-minimally involving local researchers ${ }^{16}$-and ignores universities. Deploring this disconnection between, ${ }^{17}$ the report recommends measures that paradoxically seem to contribute to reproducing this trend. One of the recommendations is indeed to integrate more local researchers in the responses to calls for bids, notably in view of "capacity building", but the report does not seek to consolidate local institutions, universities or think tanks. The overall tendency is that international organizations continue to respond to calls for bids, while simultaneously reinforcing a brain drain of researchers involved in international projects. Working more with academic institutions, mostly public institutions, is not even suggested. When this possibility was raised, during a conference presenting this report, it was immediately dismissed ${ }^{18}$ : according to the report's writers, sponsors are not in favor of supporting universities as they are considered to be failing and corrupt and for the reason that institutional support projects started twenty years ago would have had no effect (Development Initiatives 2016: 33).

The effects of international development on research production are obvious, both on the type of knowledge produced and on the training of new researchers. The conflation between these different "research" approaches and productions ("evidence collection," "surveys," "internal evaluation") hardly conceals the fact that very few of them are directed towards a better understanding of the structural causes of the humanitarian situation (social, political) in the region and that the methodologies do not allow for the collection of original and context-sensitive data. Indeed, this commissioned production of data / knowledge works through very limited and inflexible research protocols, with often quantitative and macro methods, and leave a large part to recommendations. 
14 The position of the French research institutes abroad vis-à-vis development is quite uncomfortable: they are in direct competition with organizations that only work through project calls and perfectly master the skills and networks that are necessary for capturing these budgets. These budgets are often very substantial (more than a million euros) and French research institutes, being tiny structures, cannot easily convince sponsors of their ability to manage such big financial amounts. ${ }^{19}$ Above all, the expected research objectives and methodologies strongly constrain the writing of projects with their predefined concepts, their methodological tools often shaped by technological modernization (so-called "innovative tools") and their practical recommendations. The inclusion of the French research institutes abroad in the world of research for development is far from obvious, and yet it is constantly recommended by their supervising institutions, requesting of these institutes that they be almost selfreliant and finance themselves.

\section{Conclusion}

Faced with expanding markets, the question whether the French research cooperation institutions could pool their strengths (mutualisation) and collaborate better with its European partners-if not act as one European research-has been a recurring issue that regularly collides with institutional and national boundaries. Recommended in several reports or memorandum, the pooling of French research institutes (in terms of human resources, finance, etc.) appears to be the most obvious solution in contexts where French research is in the minority and the research market dominated by extremely well-funded private organizations..$^{20} \mathrm{~A}$ change of scale seems necessary, in order to be able to set up scientific projects which would not be determined by the development agenda with its generously funded projects. The pooling and sharing of French research institutes and/or the Europeanization of partnership arrangements could provide more powerful levers to access French and European research funding, both for research projects and for training and research operations. The few European funds which have been obtained and managed by research institutes in Africa have had structuring effects on the training of young East African and European researchers, who were well-funded, engaged in varied activities and benefited from an early internationalization process. ${ }^{21}$ This is not about yielding to the illusions of the "big is beautiful", a refrain that sustains university reforms aiming to mutualize at all costs: the critical size of the French research institutes in Africa has not yet been reached, and this leap in scale seems to be the condition for a partnership that can attract (young) African researchers who adhere to the scientific options offered by the European tradition of critical research in the social sciences. The obstacles put on this type of reform seem less likely to be overcome at the French national level than at the European level. German initiative is growing on the continent and it is looking for cooperation with European colleagues, in particular French research. Such efforts could possibly lead progressively to the establishment of Afro-European partnership. In the English-speaking countries where the majority of French research institutes abroad are established, the existence of similar British structures for research could encourage institutional rapprochement, notably taking stock of the fact that initiatives for research project cooperation are already multiple. 
In the African countries hosting French research institutes, it seems necessary to give precedence to universities-and in particular to play the card of excellence-to encourage university authorities to provide more support for research and researchers. In Kenya, public authorities already focus their attention on the establishment of "quality" research systems and they are looking for institutional "models": how to empower a research center, how to evaluate these centers, as well as researchers, are all questions that arise for example from the Commission for Higher Education and from NACOSTI. ${ }^{22}$ In this regard, the spread of models that combine international standards and the specificity of social science research-one that does not rest on quantitative approaches only-seems relevant and even necessary. The risk is otherwise to see institutional divergences and the gaps between the expectations of African and of European (or French) researchers widen, which would therefore make any pursuit of partnership impossible. Even if one can take a critical look at the university reforms undertaken in France over the past ten years, the spread of a model based on the public university, public funding of research and a certain independence left to researchers could be considered as one of the main objectives of academic cooperation. The production of knowledge and the scientific advances resulting from these partnerships would only be strengthened.

\section{BIBLIOGRAPHY}

Bocquier, Philippe. 2003. "Le rôle des instituts de recherche français dans la mobilisation de la diaspora scientifique : le cas de l'Afrique sub-saharienne." In Diasporas scientifiques : comment les pays en développement peuvent-ils tirer parti de leurs chercheurs et de leurs ingénieurs expatriés ?, edited by Rémi Barré, Valeria Hernandez, Jean-Baptiste Meyer, and Dominique Vinck, 590-598. Paris: IRD Éditions. https://doi.org/10.4000/books.irdeditions.2649 [archive: http:// www.documentation.ird.fr/hor/fdi:010047997]

Bugwabari, Nicodème, Alain Cazeneuve-Piarrot, Olivier Provini and Christian Thibon, eds. 2014. Universités, universitaires en Afrique de l'Est. Hommes et sociétés. Nairobi: IFRA; Paris: Karthala.

Charton, Hélène. 1997. Le désir d'école. les initiatives africaines dans l'éducation au Kenya (1945-1978). Paris: Publications de l'Université Paris 7-Denis Diderot.

Charton, Hélène, and Samuel Owuor. 2008. "De l'intellectuel à l'expert. Les sciences sociales africaines dans la tourmente : le cas du Kenya." Revue internationale d'éducation de Sèvres, no. 49: 107-121. https://doi.org/10.4000/ries.578.

Cumming, Gordon D. 2017. "La transformation de l'AFD et de l'aide française au cours des 'années Severino': vers une nouvelle compréhension des réformes de politiques publiques." In 75 ans d'engagement : L'Agence Française de Développement, des origines à nos jours, 35-64. Paris: Agence française de développement. URL : https://www.afd.fr/fr/ressources/75-ans-au-service-du-developpement [archive]. 
Development Initiatives. 2016. "Humanitarian Evidence Systems Mapping in East Africa." Report, January. URL: https://devinit.org/resources/humanitarian-evidence-systems-mapping-in-eastafrica/ [archive].

Droz, Yvan, and Anne Mayor, eds. 2009. Partenariats scientifiques avec l'Afrique. Réflexions scientifiques de Suisse et d'ailleurs. Paris: Karthala.

Olivier de Sardan, Jean-Pierre, and Mahaman Tidjani Alou. 2012. "Le LASDEL. Construire un pôle africain en sciences sociales." Études et travaux du LASDEL no 100. URL: http://lasdel.net/ index.php/nos-activites/etudes-travaux/158-n-100-pour-une-recherche-d-excellence-enafrique-par-jean-pierre-olivier-de-sardan-tidjani-alou-mahaman-2011 [archive].

Forgeron, Loan, Pierre Lanapats, et al. 2014. "La coordination de l'action internationale en matière d'enseignement supérieur et de recherche." Rapport de l'Inspection générale des affaires étrangères no. 37-INS /Inspection générale de l'administration de l'éducation nationale et de la recherche no. 2014-003, janvier. Paris: Ministère des Affaires étrangères-Ministère de l'Enseignement supérieur et de la Recherche. URL: https://www.enseignementsuprecherche.gouv.fr/cid77620/la-coordination-de-l-action-internationale-en-matiere-denseignement-superieur-et-de-recherche.html [archive].

Leboeuf, Aline, and Hélène Quenot-Suarez. 2016. La politique africaine de la France sous François Hollande : Renouvellement et impensé stratégique. Les études de l'IFRI. Paris: Ifri. URL : https:// www.ifri.org/fr/publications/ouvrages-de-lifri/politique-africaine-de-france-francois-hollanderenouvellement [archive].

Meimon, Julien. 2007. «Que reste-t-il de la Coopération française ?» Politique africaine no.105: 2750. https://doi.org/10.3917/polaf.105.0027.

Musselin, Christine. 2017. La grande course des universités. Paris: Presses de Sciences Po.

Provini, Olivier. 2015. “La circulation des réformes universitaires en Afrique de l'Est. Les politiques de l'enseignement supérieur au regard de la sociologie de l'action publique et de l'État." Doctoral thesis in political science. Pau: Université de Pau et des Pays de l'Adour. URL: https://tel.archives-ouvertes.fr/tel-01536422.

Provini, Olivier, Cédric Mayrargue, and Ibrahim Chitou. 2020. "Étudier l'enseignement supérieur dans les Afriques : pour une analyse scientifique des réformes du secteur." Les Cahiers d'Afrique de l'Est / The East African Review no. 54. URL: http://journals.openedition.org/eastafrica/1141.

Yung, Richard. 2017. "Les Instituts français de recherche à l'étranger (IFRE), un outil de la diplomatie d'influence à mieux valoriser. Rapport d'information fait au nom de la commission des finances sur les Instituts français de recherche à l'étranger (IFRE)." Rapport d'information no. 624 (2016-2017), July 12. Paris: Présidence du Sénat. URL : https://www.senat.fr/noticerapport/2016/r16-624-notice.html [archive].

\section{NOTES}

1. The French National Centre for Scientific Research (CNRS) is the main national public research body in France, with a staff of more than 30,000 people, including approximately 11000 researchers. It supervises almost a thousand «joint research units » (UMR) together with universities. The French institutes for research abroad (UMIFRE), which are now headed both by CNRS and the French Ministry of Foreign Affairs, are part of these units. 
2. The literature on diplomatic and cooperation reforms in France is surprisingly sparse. Despite regular studies on France's African policy (corresponding to each fiveyear presidential term), there are ultimately few works of sociology of public action studying French diplomacy and cooperation. On France's recent African policy and the institutional complexity of foreign policy in Africa, see for example Leboeuf \& QuenotSuarez (2016). On the French Development Agency, see: Cumming (2017). The literature on university reforms in France is more substantial, see for instance Musselin (2017).

3. 200 researchers per year are sent on assignment abroad by the CNRS, out of its approximate 11,000 researchers.

4. See the sums of books published by the research institutes together with several French publishers, such as Karthala in France and East African publishers for example.

5. See for example the JUGURTA program on space justice coordinated by P. GervaisLambony or more recently the GLOBAFRICA program on Africa's connections with the rest of the world before slavery, coordinated by A. Delmas, to mention only the programs involving several French research institutes in sub-Saharan Africa.

6. See for instance the report of the Senate Finance Committee by Richard Yung (2017).

7. This changeover has not yet been the subject of academic studies. The remarks below are the result of observations, as close as possible to this administration, in East Africa, but also on a continental level, in particular during the author's participation in a seminar on cooperation policy bringing together all the heads of cooperation services on the continent as well as the directors of institutes, in November 2017 in Dakar.

8. For an analysis of French research institutes abroad, see for instance Forgeron, Lanapats et al. (2014); Bocquier (2003).

9. This is IFRA-Nairobi's experience in relation to a project on inequality.

10. On these reforms, in East Africa, see Provini (2015), and Bugwabari, CazeneuvePiarrot, Provini \& Thibon (2014: 195-211) ; see also the special issue of The East African Review on higher education reforms (https://journals.openedition.org/eastafrica/ 1121), notably Provini, Mayrargue \& Chitou (2020).

11. Around 4,000 euros per year for a Master's degree.

12. Daily Nation, October 8, 2016.

13. Interviews with colleagues, Nairobi, 2014-2018.

14. See Droz \& Mayor (2009); Olivier de Sardan \& Tidjani Alou (2012: 24); on Kenya, Charton \& Owuor (2008).

15. Department for International Development, the UK government's development agency.

16. The report estimates that $10 \%$ of research grants go to local institutions in East Africa (Development Initiatives 2016).

17. However, the report notes differences between donors: the IDRC (International development research center, Canadian) provides about half of research funding to local institutions, while USAID (US government development agency) donates $95 \%$ of its research funding to international institutions . (Development Initiatives 2016: 34).

18. Observations during the presentation of this report organized by the Rift Valley Institute (RVI), Nairobi, February 19, 2016. 
19. This justification was given by DFID to rule out a project proposal by IFRA-Nairobi (with two partners).

20. See for example the "Resolution of March 10, 2010" of the Scientific Council of the African IFREs, presented again to the authorities and to the COS during the Scientific Council of March 27, 2012.

21. I am thinking here of the CREATING (Cooperative Research on East African Territorial Integration within Globalization) project funded by the PRCDT (Framework Program for Research and Technological Development), a former European research funding tool of which IFRA-Nairobi was a stakeholder, and which allowed the training of a large number of East African and European students.

22. National Commission for Science and Technology of Kenya.

\section{ABSTRACTS}

This article focuses on the integration of French research institutes in Africa into the world of research in English-speaking Africa, starting by the Kenyan case. Faced with the development of a market for research guided by development donors, the institute offers a critical and independent research model but does not necessarily meet the expectations of donors or academic partners. These are indeed attracted by this lucrative market, and must respond to the injunctions of a growing academic world, which requires more lessons but also to obtain quantifiable research results. In this context, the model promoted by IFRE is minority and insufficiently attractive and could change scale, by Europeanising and developing transcontinental projects, from a single network that can be mobilised

\section{INDEX}

Geographical index: East Africa | Afrique de l'Est

Keywords: Anglophone Africa, partnerships, academic market, French research institutes, UMIFRE

\section{AUTHOR}

\section{MARIE-EMMANUELLE POMMEROLLE}

Institut des mondes africains, Université Paris 1 Panthéon Sorbonne. 